\title{
Highly Selective Synthesis of High Octane-Number Gasoline from Light Olefins on Fe-Silicates
}

\author{
Tomoyuki Inu*,, Fumio Orazumi, Junichi Tarumoto, Osamu Yamase, \\ Hirokazu Matsuda, Hideo Nagata, Noboru Daito, and Akira Miyamoto \\ Department of Hydrocarbon Chemistry, Faculty of Engineering, \\ Kyoto University, Sakyo-ku, Kyoto 606
}

(Received October 23, 1986)

\begin{abstract}
The conversion of light olefins such as ethylene, propylene, and butenes to gasoline was investigated with various metallosilicates having a pentasil pore-opening structure. The metallosilicates were prepared using a novel rapid crystallization method by replacing the $\mathrm{Al}$ ingredient in the H-ZSM-5 with various metal salts at the gel formation stage. The silicates of $\mathrm{Al}$ (i.e., H-ZSM-5), Ga, V, Cr, and $\mathrm{Zr}$ were not highly effective for selective conversion to liquid products because of a significant formation of gaseous $\mathrm{C}_{1}-\mathrm{C}_{4}$ paraffins accompanied with the formation of aromatics. On the other hand, Fe-silicates were highly effective for selective formation of liquid products in the gasoline fraction. For example, $95.6 \%$ propylene fed was converted under the space velocity of $4,500 \mathrm{~h}^{-1}$ and at $300^{\circ} \mathrm{C}$ to the liquid products with a space-time yield as high as $8.09 \mathrm{~kg} / l \cdot \mathrm{h}$. The octane-number of the gasoline produced was as high as 95 because of the high percentage of branched internal-olefins found in the liquid products. The Fe-silicate exhibited high activity and selectivity under various conditions, and maintained its steady performance at least $100 \mathrm{~h}$ on stream. The reason for this high gasoline selectivity of Fe-silicate was discussed in relation to its properties and performance in methanol conversion to hydrocarbons.
\end{abstract}

\section{Introduction}

Since the oil crisis, heavy oil has been replaced by coal in the steel industries, and in the electric power and other large scale energy generation systems. Accordingly, the excessive supply of heavy oil has become a serious problem, and to develop new routes for effective utilization of heavy oil has become of great significance. This paper concerns with the subject and aims at developing a new synthesis route for high octane-number gasoline from light olefins which are produced by thermal cracking of heavy oil.

Conventional processes for thermal cracking of residual oil produce considerable amounts of light olefins besides gasoline, kerosene, light oil, and coke. ${ }^{1)}$ Since the yield of gasoline $\left(\mathrm{C}_{5}-\mathrm{C}_{11}\right.$ hydrocarbons) is not high enough in the conventional processes, successive conversion to gasoline of the light olefins is expected. As conventional catalysts for polymer gasoline synthesis from light olefins, solid phosphoric acid, supported nickel oxide, and sulfuric acid are known. ${ }^{2), 3)}$ From the industrial

\footnotetext{
* To whom correspondence should be addressed.
}

point of view, however, the performance of these catalysts is insufficient because of such negative factors as low activity for and selectivity to gasoline formation, short catalyst life, corrosive action on the reactor, and low octane-number of the gasoline produced. ${ }^{4}$ )

Recently, it has been reported that H-ZSM-5 is effective for conversion of light olefins to gasoline fraction ${ }^{4)}$ ) ; however, its selectivity to gasoline fraction is inadequate because it forms considerable amounts of gaseous light paraffins $\left(\mathbf{C}_{\mathbf{1}}-\mathrm{C}_{\mathbf{4}}\right)$ accompanied with the formation of aromatics.4),5),8),9) The aromatization activity of H-ZSM-5 is due to its strong acid sites brought about by the $\mathrm{Al}$ cations in ZSM-5. 10) 12)

In order to modify the acidic properties and pore diameters, we replaced $\mathrm{Al}$ with other elements with maintaining a pentasil pore-opening structure and three dimensional pore connection of ZSM-5.4),8), 9),13),14) This was done because such pore structure of ZSM-5 is considered to be the reason for shape selectivity and long catalyst life. ${ }^{15), 16)}$ Though metallosilicate synthesis has also been studied by other authors ${ }^{17) ~ 19)}$, its application to cat- 


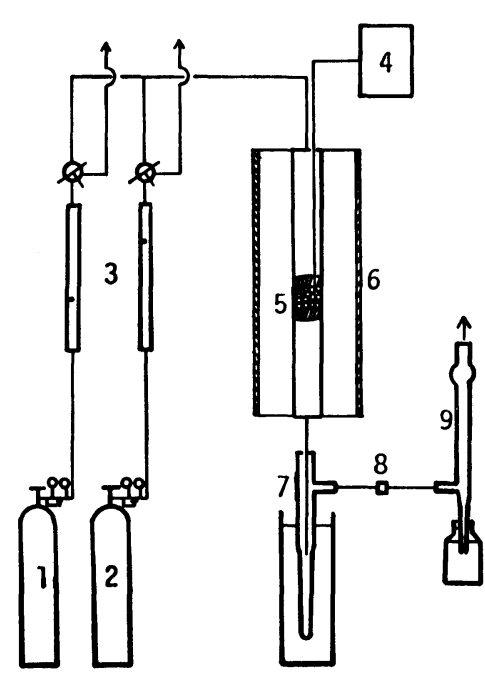

(a)

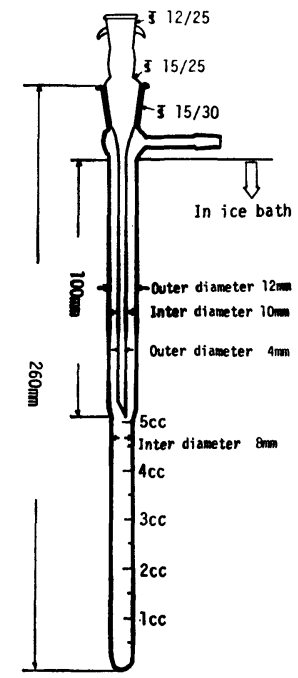

(b)

1, $\mathrm{N}_{2}$ gas cylinder; 2, olefin gas cylinder; 3 , flow meter; 4, temperature controller; 5 , quartz tube reactor (i.d. $8 \mathrm{~mm}$ ); 6 , electric furnace; 7 , liquid trap; 8 , gas sampling port; 9, soap film flow meter

Fig. 1 Schematic Diagram for the Continuous Flow Reaction Apparatus (a) and Details of the Liquid Trap (b)

alytic reactions has not yet been investigated extensively. The effect of such metal replacement on the selectivity to hydrocarbons from methanol has been reported in our previous papers. ${ }^{8), 13), 14)}$

In this paper, we described the effect of metal replacement on light olefin conversion; also we focused our interest on the performance of $\mathrm{Fe}-$ silicate which exhibited the most best result for gasoline synthesis among the various metallosilicates tested.

\section{Experimental}

Catalysts: H-ZSM-5 was prepared by the rapid crystallization method ${ }^{8}$, and various kinds of metallosilicates were prepared by replacing the $\mathrm{Al}$ ingredient with other metal salts at the gel-formation stage of the ZSM-5 preparations. Principles and concrete procedures have been described in detail in our previous papers. ${ }^{4), 8), 13), 14)}$ All the catalysts in a grain-size of 7-15 mesh were used as the protonated form.

Fe-silicates with various $\mathrm{Fe}$ contents were prepared by adopting also the rapid crystallization method. ${ }^{14)}$ The observed $\mathrm{Fe}$ concentrations in the products were almost equal to those of the charged materials, and increased with increasing charged concentration of $\mathrm{Fe}$ in the starting materials up to the $\mathrm{Si} / \mathrm{Fe}$ ratio $12\left(10 \mathrm{wt} \%\right.$ as $\left.\mathrm{Fe}_{2} \mathrm{O}_{3}\right)$. Since the $\mathrm{X}$-ray diffraction patterns of Fe-silicates were almost the same as the pattern of ZSM-5, various amounts of $\mathrm{Fe}$ are incorporated in the silicate crystal having the pentasil structure. In consistent with recent investigations of $\mathrm{Fe}$-silicate with solid state MAS NMR ${ }^{20)}$, ESR spectra of the Fe-silicate suggests that $\mathrm{Fe}$ ion be highly dispersed in the crystal, and a considerable part of $\mathrm{Fe}^{3+}$ ions occupies the framework of silicate crystal. The color of $\mathrm{Fe}$-silicate (milk-white even for the catalyst with the highest $\mathrm{Fe}$ content) and the negligible activity for $\mathrm{CO}$ hydrogenation are in accordance with the idea. TPD spectra of $\mathrm{NH}_{3}$ from the Fe-silicates indicated that the $\mathrm{Fe}$ ion incorporated in the crystal was responsible for the formation of acid sites, and the acid strength of Fe-silicate was weaker than that of H-ZSM-5. Furthermore, SEM (scanning electron microscope) and EPMA (electron probe micro-analysis) measurements indicated that a small amount of Fe acted as the nucleus in the growth of high-silica crystal to change the morphology and that the Fe concentration inside the crystal was higher than the concentration at outer surface layers of the crystal particulate. Detailed data of these observations have been described in our previous paper. ${ }^{14)}$

Apparatus and reaction method: An ordinary continuous flow reaction apparatus was used under atmospheric pressure. A schematic diagram of the apparatus and the liquid-products trap immersed in an ice-water bath are shown in Fig. 1(a) and Fig. 1 (b), respectively. A $1.0 \mathrm{~g}$ (or ca. $1.5 \mathrm{~m} l$ ) portion of the catalyst was packed in a transparent quartz tubular reactor of $8 \mathrm{~mm}$ inner diameter and pre- 
treated with an $\mathrm{N}_{2}$ flow at $500^{\circ} \mathrm{C}$ for $30 \mathrm{~min}$ to normalize the catalyst surface conditions by removal of the adsorbed $\mathrm{H}_{2} \mathrm{O}$. A reactant gas was fed to the reactor, and the gas produced was led to the cooled trap. The integrated formation rate of liquid products was determined by measuring the amount of the liquids during a definite time on stream, while the formation rate of gaseous products was determined by measuring the flow rate using a soap film flow meter. The liquid and gaseous products were analyzed by using three gas chromatographs simultaneously. Columns of MS-5A, VZ-10, and Silicone-OV-101 were used to analyze the whole range of hydrocarbons produced and hydrogen. Each gas chromatograph was equipped with an integrator. Research octane number of the liquid products was measured conventionally according to the formula of JIS K-2280.

The reaction was carried out under the following conditions: reactants: ethylene, propylene, or butenes; reaction temperature: $260-360^{\circ} \mathrm{C}$; space velocity $900-4,500 \mathrm{~h}^{-1}$; and $\mathrm{N}_{2}$ was used as the diluent when needed.

\section{Results and Discussion}

\subsection{Comparison of Performance of Various Metallosilicates for Propylene Conversion}

The results of propylene conversion performance on various metallosilicates were compared by using a feed gas mixture of $17 \% \mathrm{C}_{3} \mathrm{H}_{6}-83 \% \mathrm{~N}_{2}$. All the metallosilicates used exhibited activities adequate for propylene oligomerization, and attained conversion level above $96 \%$ at temperatures as low as $295^{\circ} \mathrm{C}$. The product distribution for each catalyst is shown in Fig. 2. Among the hydrocarbons produced, butenes, $\mathrm{C}_{5}-\mathrm{C}_{11}$ aliphatics, and aromatics

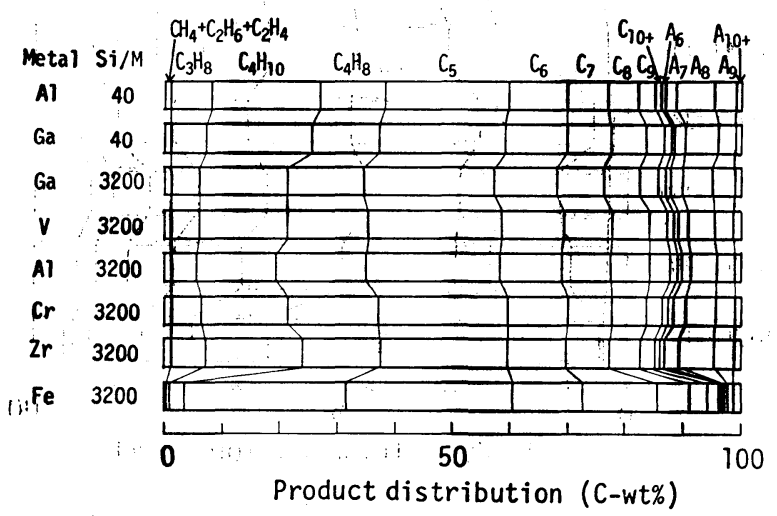

Feed gas, $17 \%$ propylene and $83 \% \mathrm{~N}_{2}$; temperature, $295^{\circ} \mathrm{C}$; SV, $900 \mathrm{~h}^{-1}$

Fig. 2 Product Distribution in the Propylene Conversion on Various Metallosilicates and H-ZSM-5's were trapped mainly in the ice-cooled trap, while light paraffins $\left(\mathrm{C}_{1}-\mathrm{C}_{4}\right)$ and ethylene were found mainly in the gas phase. Thus, we define, hereafter, the hydrocarbons trapped in the icecooled trap as liquid products in discussing changes in product distribution with the catalyst. A typical H-ZSM-5, Al-silicate having $\mathrm{Si} / \mathrm{Al}$ ratio 40 , yielded considerable amounts of aromatics and $\mathrm{C}_{1}-\mathrm{C}_{4}$ paraffins in addition to butenes and $\mathrm{C}_{5}-\mathrm{C}_{11}$ aliphatics. The $\mathrm{Ga}$ silicate of a high $\mathrm{Ga}$ content $(\mathrm{Si} / \mathrm{Ga}=40)$ gave substantially similar results, although the amounts of aromatics and light paraffins decreased somewhat. Low metal-content metallosilicates ( $\mathrm{Si} / \mathrm{Metal}=$ 3,200), except Fe-silicate, gave similar results to those of H-ZSM-5 of low Al content. On the other hand, the Fe-silicate gave a significantly different product distribution, i.e., traces of light paraffins were formed, and the selectivity to liquid products was very high. All light paraffins and butenes dissolved in the gasoline fraction. From the comparison of the results of low- and high-metal-content catalysts, any remarkable change in product selectivity would not be expected by merely changing the metal content; only the kind of metal, especially $\mathrm{Fe}$, incorporated in the silicate crystal could bring about any significant improvement in the product selectivity for gasoline synthesis.

\subsection{Effect of Si/Fe Ratio in Fe-Silicate on Performance}

To confirm the excellent performance of the Fesilicate more precisely, propylene conversion on Fesilicates with different $\mathrm{Si} / \mathrm{Fe}$ ratios was performed using nondiluted propylene as the reactant. Other reaction conditions were similar to those of experiments described above.

The product distributions are shown in Fig. 3. Notwithstanding the use of nondiluted propylene, the conversion was almost complete for all catalysts compared. As for H-ZSM-5's, although the selectivity to aromatics increased and that to $\mathrm{C}_{1}-\mathrm{C}_{4}$ paraffins decreased compared with the results of the experiments using diluted propylene, there was no significant change in the product distribution between the two H-ZSM-5's, Si/Al=3,200 and 40 . On the other hand, in the case of Fe-silicates, when the $\mathrm{Si} / \mathrm{Fe}$ ratio was 3,200 or 12 , the selectivity to $\mathrm{C}_{1}-\mathrm{C}_{4}$ paraffins was very low, but the Fe-silicates having $\mathrm{Si} / \mathrm{Fe}$ ratios 400 and 40 gave similar results as did the H-ZSM-5's.

In our previous paper ${ }^{14)}$, we described the dependence of the number of strong acid sites on the Fe content of Fe-silicate based on the results of TPD 


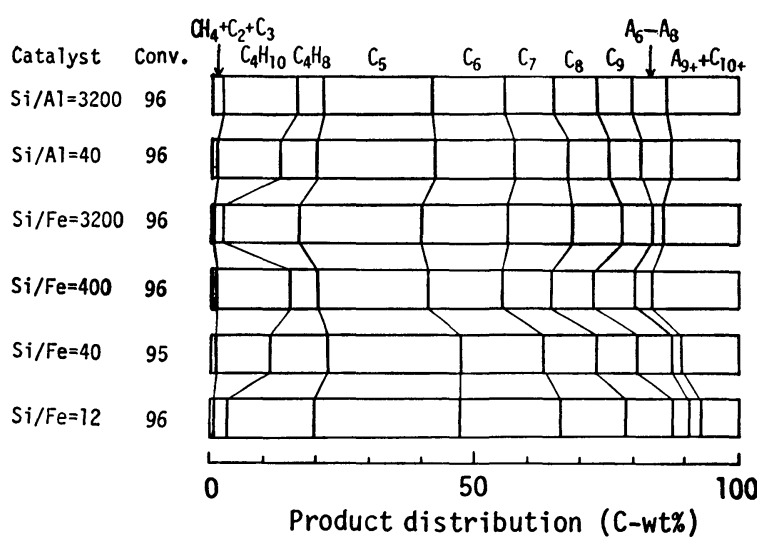

Feed gas, $100 \%$ propylene; temperature, $300^{\circ} \mathrm{C}$; $\mathrm{SV}, 1,000 \mathrm{~h}^{-1}$

Fig. 3 Product Distribution in the Propylene Conversion on Fe-Silicates and H-ZSM-5's with Different Si/Metal Ratios

measurements for adsorbed $\mathrm{NH}_{3}$. According to this dependence, the number of strong acid sites increases with increase in the $\mathrm{Fe}$ content as $\mathrm{Fe}_{2} \mathrm{O}_{3}$ up to about $5 \mathrm{wt} \%$, the number of strong acid sites decreases with further increase in the Fe content. $\mathrm{Fe}$-silicates of higher $\mathrm{Fe}$ contents lacked sufficient crystallinity compared with the others. This feature related to the number of strong acid sites is reflected on the selectivity of aromatics and light olefins from methanol; namely, aromatics and light paraffins increase with increasing number of strong acid sites and vice versa for light olefins. The results of propylene conversion observed in this study are in good accord with those of methanol conversion considered from the viewpoint of the relation between the number of acid sites and the yields of aromatics or of $\mathrm{C}_{1}-\mathrm{C}_{4}$ light paraffins.

The principal reaction scheme for methanol conversion to hydrocarbon on H-ZSM-5 has been proposed based on the results in accord with a number of researchers ${ }^{10), 11), 21), 22)}$ as follows:

$\mathrm{MeOH} \rightarrow \mathrm{MeOMe} \rightarrow$

$$
\mathrm{C}_{2}-\mathrm{C}_{6} \text { olefins } \backslash_{\mathrm{C}_{6}-\mathrm{C}_{11} \text { aliphatic hydrocarbons }}^{\text {aromatics and paraffins }}
$$

and it is obvious that strong acid sites on H-ZSM-5 are responsible for the aromatization from light olefins and also for the hydrogenation of light olefins with the hydrogen formed accompanying aromatization. ${ }^{12), 23)}$

The latter half of the above reaction scheme would be considered as olefin conversion on H-ZSM-5 although there are no methanol and/or dimethyl ether and water in the reactant. Actually, the result of olefin conversion on H-ZSM- 5 can well be implied by this reaction scheme. However, the main reaction path on the $\mathrm{Fe}$-silicates having $\mathrm{Si} / \mathrm{Fe}$ ratios 3,200 and 12 lacks aromatization and hydrogenation, indicating that the nature of acid sites is different from that of H-ZSM-5, i.e., somewhat weaker than H-ZSM- 5 as we have observed in the $\mathrm{NH}_{3}$-TPD profiles. ${ }^{14), 24)}$

\subsection{Extension to Butenes and Ethylene Gon- versions}

Butenes were converted on the catalysts used in the propylene conversion under the same temperature and space velocity as noted in Fig. 3, and the results of 1-butene conversion are shown in Fig. 4. In these experiments, the feed 1-butene could not be differentiated from the 1-butene produced by isomerization and/or by cracking. Therefore, from Fig. 4 of product distribution, 1-butene was eliminated. Although the introduction of this numerical ambiguity, the general trend of Fig. 4 consistently coincides with the results of propylene conversion shown in Fig. 3. Similar results were also obtained for other three butene isomers.

As we reported earlier ${ }^{9}$, the rate of ethylene conversion is much lower than the rates of propylene and butenes conversions. Therefore, the reaction was carried out at $330^{\circ} \mathrm{C}$ which was higher by $30^{\circ} \mathrm{C}$ than that used for propylene and butenes conversions. The results are shown in Fig. 5. Even at $330^{\circ} \mathrm{C}$, ethylene conversions on the $\mathrm{Fe}$-silicates of $\mathrm{Si} / \mathrm{Fe} 3,200$ and 12 were only 51 and $4 \%$, respectively; whereas on the H-ZSM-5's and Fesilicates of $\mathrm{Si} / \mathrm{Fe} 400$ and 40 , these catalysts substantially completed the conversion of ethylene. The result that the selectivity to aromatics and to light paraffins increased at higher reaction tem-

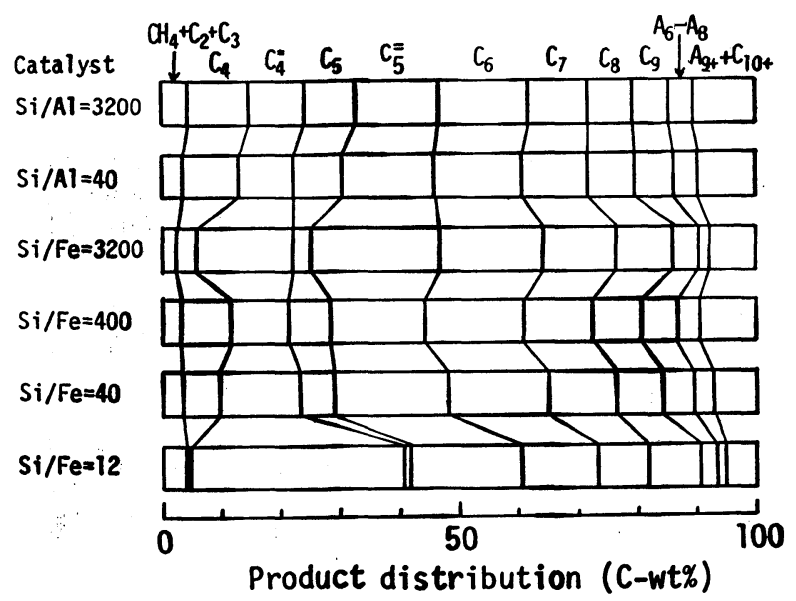

Feed gas, $100 \%$ 1-butene; temperature, $300^{\circ} \mathrm{C}$; $\mathrm{SV}, 1,000 \mathrm{~h}^{-1}$

Fig. 4 Product Distribution in the 1-Butene Conversion on Fe-Silicates and H-ZSM-5's with Different $\mathrm{Si} /$ Metal Ratios 


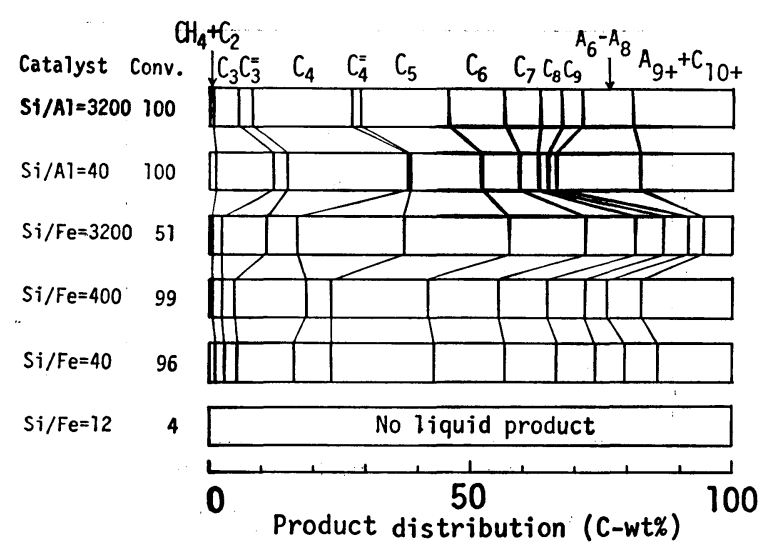

Feed gas, $100 \%$ ethylene; temperature, $330^{\circ} \mathrm{C}$; $\mathrm{SV}, 1,000 \mathrm{~h}^{-1}$

Fig. 5 Product Distribution in the Ethylene Conversion on Fe-Silicates and H-ZSM-5's with Different Si/Metal Ratios

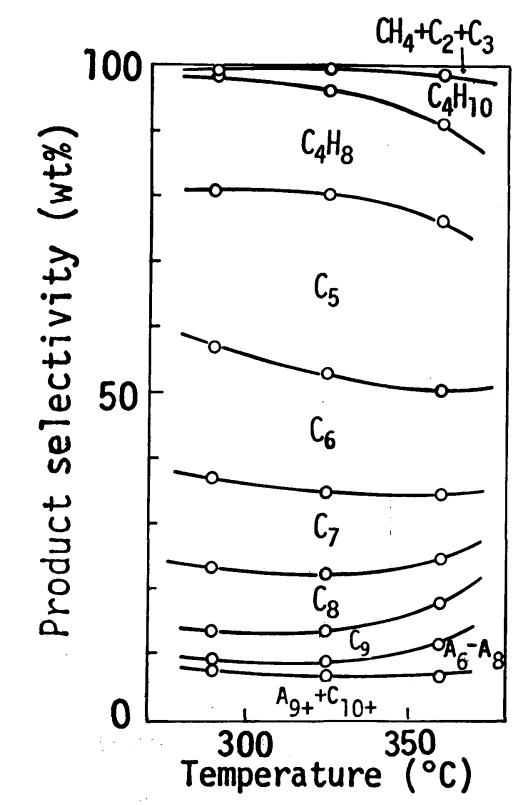

Feed gas, $100 \%$ Propylene; SV, 1,000 $\mathrm{h}^{-1}$

Fig. 6 Effect of Temperature on the Product Distribution in the Propylene Conversion on the FeSilicate Having $\mathrm{Si} / \mathrm{Fe}$ Ratio 3,200

peratures on the H-ZSM-5's is a specific trend indicated by H-ZSM-5's. In the case of the two active $\mathrm{Fe}$-silicates, their selectivities to aromatics and light paraffins were lower than those of the $\mathrm{H}$ ZSM-5's. In other words, the specific catalytic properties of H-ZSM-5 and Fe-silicate which appeared in the propylene and butenes conversions exerted more specifically in the ethylene conversion.

3.4 Performance of the Fe-Silicate for Propylene Conversion under Various Reaction Gonditions

Using the Fe-silicate of $\mathrm{Si} / \mathrm{Fe}$ ratio 3,200 , the

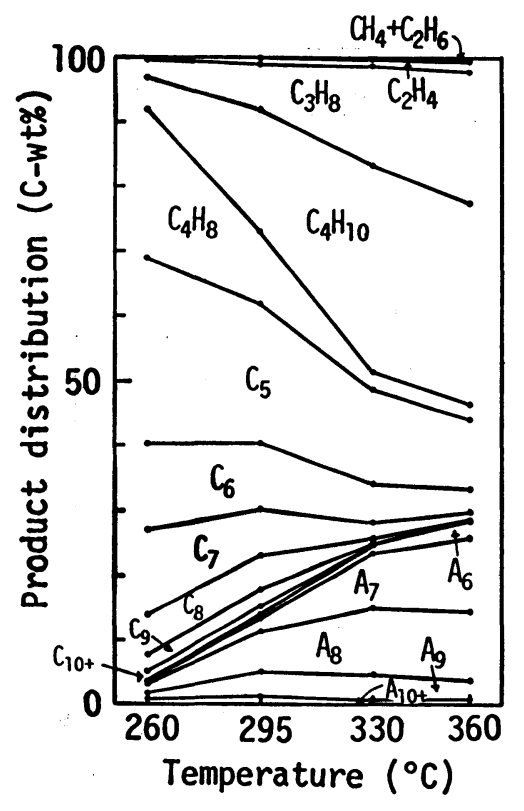

Feed gas, $17 \%$ propylene; SV, $900 \mathrm{~h}^{-1}$

Fig. 7 Effect of Temperature on the Product Distribution in the Propylene Conversion on a Typical H-ZSM-5

effect of temperature on the product distribution was tested. In the whole temperature range tested, the propylene conversion was more than $96 \%$. The hydrocarbon distribution obtained at each temperature is plotted in Fig. 6. To compare it with the result of a typical H-ZSM-5, the propylene conversion on $\mathrm{H}-\mathrm{ZSM}-5$ of $\mathrm{Si} / \mathrm{Al}$ ratio 40 is shown in Fig. 7. The reaction conditions were the same as those of Fig. 6. At the reaction temperatures of 290 and $325^{\circ} \mathrm{C}$, the Fe-silicate converted propylene to liquid products almost completely. The contents of aromatics and light paraffins were very low and, even at $360^{\circ} \mathrm{C}$, these products increased but slightly. On the other hand, the H-ZSM-5 yielded considerable amounts of aromatics and light paraffins which increased with increasing temperature. The selectivity to $\mathrm{C}_{1}-\mathrm{C}_{4}$ paraffins of the $\mathrm{H}$ ZSM-5 was 6.2 times that of the Fe-silicate at $360^{\circ} \mathrm{C}$.

In Fig. 8, the effect of propylene concentration in the propylene conversion on the Fe-silicate is shown. The propylene concentration was allowed to vary from 27 to $100 \%$, using $\mathrm{N}_{2}$ as the diluent. The total space velocity of the gas mixture was maintained at $900 \mathrm{~h}^{-1}$. Irrespective of the propylene concentration, almost a complete conversion of propylene was achieved. The selectivity to $\mathrm{C}_{1}$ $\mathrm{C}_{4}$ paraffins was almost always small. The $\mathrm{C}_{5}{ }^{+}$ hydrocarbons, which consisted mainly of olefins, as will be mentioned later, increased remarkably with increasing propylene concentration from 27 to 


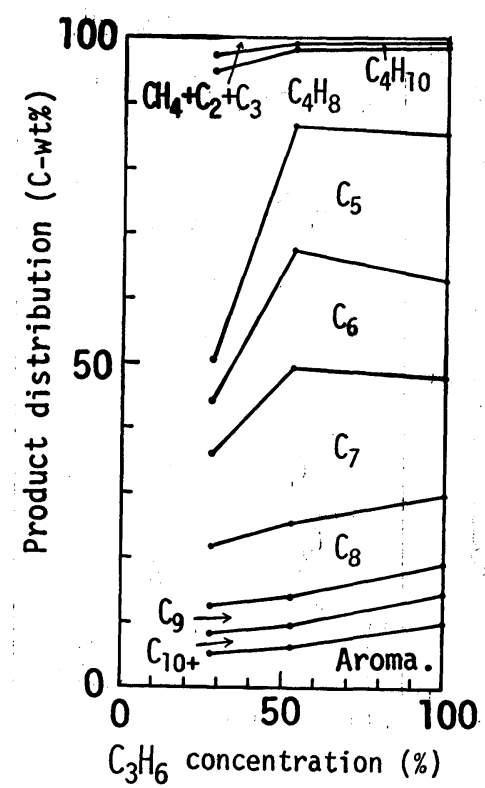

Catalyst, Fe-silicate having $\mathrm{Si} / \mathrm{Fe}$ ratio 3,200 ; Temperature, $295^{\circ} \mathrm{C}$; Diluent of propylene, $\mathrm{N}_{2} ; \mathrm{SV}, 900 \mathrm{~h}^{-1}$

Fig. 8 Effect of Propylene Concentration on the Product Distribution in the Propylene Conversion

$53 \%$, and above that concentration, the gasoline fraction attained ca. $87 \%$ even when the dissolved butenes (ca. 10\%) was not taken into account.

The effect of space velocity (SV) on the propylene conversion on the Fe-silicate was then observed. The results are shown in Figs. 9 and 10. Surprisingly, the propylene fed had almost completely converted to liquid hydrocarbons even at such SV as high as $4,500 \mathrm{~h}^{-1}$; the space-time conversion (STG) was $8.09 \mathrm{~kg}$ per liter catalyst per hour. Although the gasoline fraction $\left(\mathrm{C}_{5}-\mathrm{C}_{11}\right)$ in the liquid product decreased with increasing $\mathrm{SV}$ (Figs. 9 and 10), this decrease was due to the increase in butenes as the selectivity to light paraffins remained small for all SV's. The extraordinary high space-time conversion of propylene or spacetime yield (STY) of gasoline fraction indicates that diffusion resistance of this catalyst is very low, and there is no retardation by such phenomena as coke formation and strong adsorption of high molecular hydrocarbons in the vicinity of active sites. The absence of retardation is consistent with the weaker acidity of Fe-silicate than that of H-ZSM-5, while the rapid diffusion may be due to (1) the fine crystal size $(0.5-1 \mu \mathrm{m})$ and (2) the presence of silica-rich layers at the outer surface of Fe-silicate crystal to decrease the coke formation at the outer surface layers. ${ }^{14)}$ The rapid diffusion is also favorable for decreasing the formation of light paraffins, because

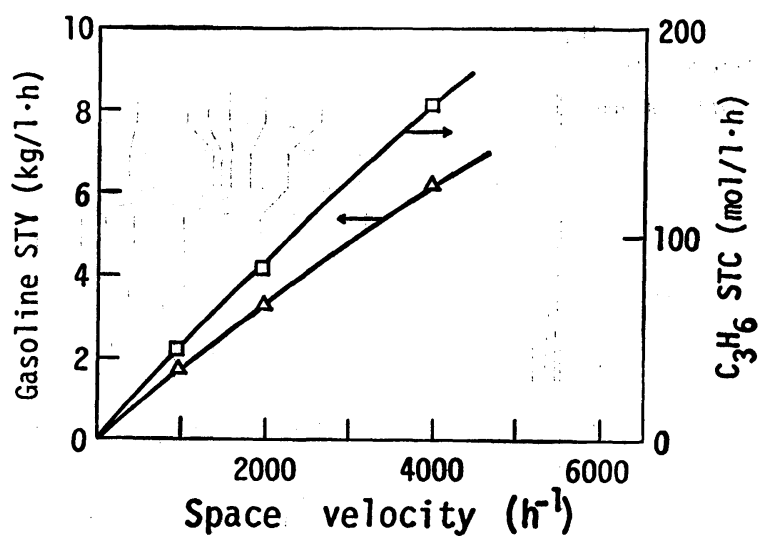

Catalyst, Fe-silicate having $\mathrm{Si} / \mathrm{Fe}$ ratio 3,200

Feed gas, $100 \%$ propylene; temperature, $300^{\circ} \mathrm{C}$

Fig. 9 Effect of Space Velocity on the Space Time Conversion of Propylene and the Space Time Yield of Gasoline Fraction

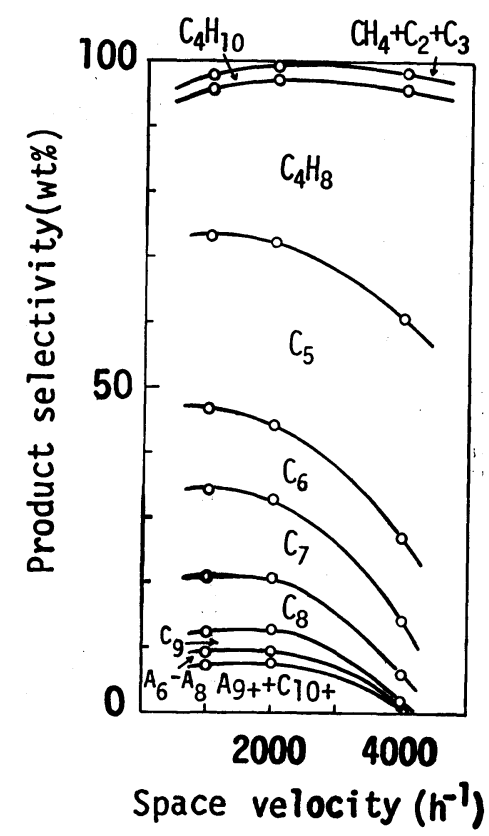

Catalyst and reaction conditions are same as Fig. 9

Fig. 10 Effect of Space Velocity on the Product Distribution in the Propylene Conversion

the olefins produced can be desorbed easily from the crystal to decrease the consecutive reaction to light paraffins and aromatics.

\subsection{Catalyst Life Test}

Tests on catalyst life over the Fe-silicate of $\mathrm{Si} / \mathrm{Fe}$ ratio 3,200 was carried out $100 \mathrm{~h}$ on stream. The high propylene conversion was maintained throughout the test without any change. In the first $30 \mathrm{~h}$, butane and aromatics decreased and after that period, the product distribution was consistently maintained. Although the light brown color of fresh catalyst changed slightly to yellowish brown 
Table 1 Olefin/Paraffin Ratio in the Product Hydrocarbon for the Propylene Conversion on the Fe-Silicate

\begin{tabular}{|c|c|c|c|}
\hline \multirow{2}{*}{ Hydrocarbon } & \multicolumn{3}{|c|}{ Reaction Temperature $\left({ }^{\circ} \mathrm{C}\right)$} \\
\hline & 290 & 325 & 360 \\
\hline $\begin{array}{l}\mathrm{C}_{2} \\
\mathrm{C}_{4} \\
\mathrm{C}_{5} \\
\mathrm{C}_{6} \\
\mathrm{C}_{7}\end{array}$ & $\begin{array}{r}24.8 \\
23.8 \\
15.2 \\
4.6 \\
2.1\end{array}$ & $\begin{array}{r}38.6 \\
5.3 \\
7.5 \\
2.8 \\
3.0\end{array}$ & $\begin{array}{r}38.3 \\
2.0 \\
2.4 \\
1.3 \\
1.7\end{array}$ \\
\hline
\end{tabular}

Catalyst : Fe-silicate having $\mathrm{Si} / \mathrm{Fe} \mathrm{3,200}$

Feed gas : $100 \%$ propylene, $\mathrm{SV}: 1,000 \mathrm{~h}^{-1}$

Table 2 Distribution of $\mathrm{C}_{5}$ Olefins in the Product for the Propylene Conversion on the $\mathrm{Fe}$ Silicate

\begin{tabular}{|c|c|c|c|}
\hline \multirow{2}{*}{ Olefin } & \multicolumn{3}{|c|}{ Reaction temperature $\left({ }^{\circ} \mathrm{C}\right)$} \\
\hline & 290 & 325 & 360 \\
\hline 3-Methyl-1-butene & $1.3 \%$ & $1.8 \%$ & $2.4 \%$ \\
\hline 1-Pentene & 2.9 & 2.2 & 3.0 \\
\hline 2-Methyl-1-butene & 14.1 & 18.4 & 20.1 \\
\hline trans-2-Pentene & 18.8 & 12.3 & 13.2 \\
\hline cis-2-Pentene & 8.2 & 5.7 & 6.5 \\
\hline 2-Methyl-2-butene & 54.6 & 59.6 & 54.8 \\
\hline Cyclopentene & 0.1 & 0.0 & 0.0 \\
\hline
\end{tabular}

Catalyst : Fe-silicate having $\mathrm{Si} / \mathrm{Fe}$ ratio 3,200

Feed gas : $100 \%$ propylene, SV : $1,000 \mathrm{~h}^{-1}$

during the first $30 \mathrm{~h}$, further change in color was not observed. This indicates that in early periods of reaction, the relatively strong acid sites, which provide active sites for aromatization and hydrogenation of olefins are covered with the coke formed, but after that the weaker acid sites perform without any coke formation and realize long catalyst life at least of $100 \mathrm{~h}$ on stream.

\subsection{Properties of the Product}

The gasoline fraction produced by the propylene conversion on the $\mathrm{Fe}$-silicate during the steady selectivity period had a research octane-number 95 . The olefin/paraffin ratio for each carbon-number molecule in the product and the distribution of pentene isomers are presented in Tables $\mathbf{1}$ and 2, respectively. The content of aromatics, which contribute to upgrading the octane-number, was low. However, as can be seen from Table 1, the olefin/ paraffin ratio is large for any carbon number; and from Table 2, it is obvious that branched internalolefins which themselves have high octane-values and which contribute to the high octane-number of the gasoline fraction are predominantly produced.

\subsection{Specific Feature of Light Olefin Con- version on the Fe-Silicate}

Based on the above observations, the principal reaction schemes for light olefin conversion on the
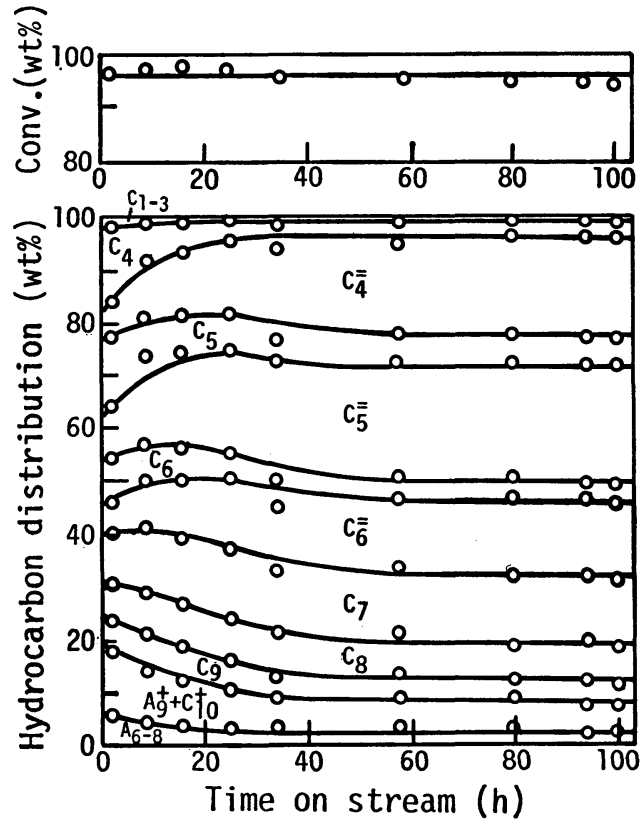

Catalyst, Fe-silicate having $\mathrm{Si} / \mathrm{Fe}$ ratio 3,200 Feed gas, $100 \%$ propylene; temperature, $300^{\circ} \mathrm{C}$; SV, $1,000 \mathrm{~h}^{-1}$

Fig. 11 Catalyst Life Test for the Fe-Silicate

Fe-silicates, which have very low activities for the formation of light paraffins and aromatics, can be derived as follows.

1. Oligomerization:

$\begin{array}{lcl}\left(\mathrm{CH}_{2}\right)_{n} & \left(\mathrm{CH}_{2}\right)_{m} & (m>n) \\ \text { light olefins } & \text { olefins } & (4 \leqq m \leqq 11)\end{array}$

2. Isomerization: The skeletal isomerization from $n$-olefins to iso-olefins and the double-bond isomerization from $\alpha$-olefins to internal olefins.

3. Cracking: Cracking of oligomers to other olefins. Besides the above principal reactions, the following disproportionation reaction occurs concomitantly during early reaction times on stream.

4. Disproportionation:

$$
\begin{aligned}
& \left(\mathrm{CH}_{2}\right)_{m} \longrightarrow \mathrm{C}_{j} \mathrm{H}_{2 j^{+2}}+\mathrm{C}_{6{ }^{+}{ }_{k}} \mathrm{H}_{6}{ }^{+2 k} \\
& (k=0,1,2,3) \\
& \text { olefins paraffins aromatics }
\end{aligned}
$$

On H-ZSM-5, reaction (4) occurs as a result of oligomerization of the light olefins. On Fe-silicate, on the other hand, reactions (1), (2), and (3) proceed selectively to give principally branched mono-internal olefins. Furthermore, there is almost no coke formation via fused-ring aromatics formation. This guarantees a long catalyst life, maintaining high activity and selectivity. Although the selectivity to liquid products for H-ZSM-5 increased considerably by decreasing the reaction temperature to $260^{\circ} \mathrm{C}$ (Fig. 7), the numerical value 
was still lower than that for Fe-silicate. Furthermore, the decrease in reaction temperature led to a decrease in conversion (ca. $60 \%$ at $260^{\circ} \mathrm{C}$ ) and in catalyst life, indicating that the excellent catalytic performance of Fe-silicate could not be realized by merely decreasing the reaction temperature on H-ZSM-5.

The Fe-silicate has been revealed to be highly effective for the conversion of light olefins to liquid products (butenes, $\mathrm{C}_{5}-\mathrm{C}_{11}$ aliphatics, and small amounts of aromatics). Since the gasoline fraction is considered to be composed of $\mathrm{C}_{5}-\mathrm{C}_{11}$ hydrocarbons, high selectivity to liquid products does not necessarily mean high selectivity to gasoline fraction. On the Fe-silicate, however, butenes could also be converted to liquid product as des. cribed above. Therefore, recirculation of butenes or increase in contact time on the Fe-silicate would lead almost to a complete conversion of light olefins to the gasoline fraction. Such high selectivity to the gasoline fraction cannot be expected on $\mathrm{H}-\mathrm{ZSM}-5$, on which light paraffins $\left(\mathrm{C}_{1}-\mathrm{C}_{4}\right.$ paraffins) cannot be converted selectively to the gasoline fraction. It should also be noted that commercial gasolines often dissolve butenes in addition to $\mathrm{C}_{5}-\mathrm{C}_{11}$ hydrocarbons, especially in the winter season. Consequently, the present study clearly indicates the availability of the Fe-silicate for selective conversion of light olefins to high octanenumber gasolines.

\section{References}

1) Heavy Oil Processing Handbook, The_Chemical Daily Co. Ltd., 1982.

2) Schmepling, L., Ipatieff, V. N., Adv. Catal., 2, 21 (1950) and references therein.

3) Jones, E. K., Adv. Catal., 8, 219 (1956) and references therein.

4) Inui, T., Yukigoseikagaku-kyokaishi, 44, 60 (1986).

5) Dejaifve, P., Védrine, J. C., Bolis, V., Derouane, E. G., J. Catal., 63, 331 (1980).

6) van den Berg, J. P., Wolthuizen, J. P., van Hooff, J. H. C., J. Catal., 80, 139 (1983).

7) Nayak, V.S., Choudhary, V. R., Appl. Catal., 9, 251
(1984).

8) Inui, T., Yamase, O., Fukuda, K., Itoh, A., Tarumoto, J., Morinaga, N., Hagiwara, T., Takegami, Y., "Proceedings, 8th International Congress on Catalysis, Berlin, 1984," Vol. 3, p. 569 (1984), Dechema, Frankfurtam-Main.

9) Inui, T., Matsuda, H., Fukuda, K., Ukawa, T., Nagata, H., Chem. Express, 1, 49 (1986).

10) Chang, C. D., Silvestri, A. J., J. Catal., 47, 249 (1977).

11) Chang, C. D., Catal. Rev., 25, 1 (1983).

12) Inui, T., Matsuda, H., Takegami, Y., "Proceedings, 6th International Conference on Zeolite, Reno, 1984" (D. Olson and A. Bisio, Eds.), p. 316 (1984), Butterworths, London.

13) Inui, T., Medhanavyn, D., Praserthdam, P., Fukuda, K., Ukawa, T., Sakamoto, A., Miyamoto, A., Appl. Catal., 18, 311 (1985).

14) Inui, T., Matsuda, H., Yamase, O., Nagata, H., Fukuda, K., Ukawa, T., Miyamoto, A., J. Catal., 98, 491 (1986).

15) Dejaifve, P., Aurou, A., Gravelle, P. C., Védrine, J. C., Gabelica, Z., Derouane, E. G., J. Catal., 70, 123 (1981).

16) Inui, T., Shokubai (Catalyst), 25, 261 (1983).

17) Ione, K. G., Vostrikova, L. A., Petrova, A. V., Mastikhin, V. M., "Proceedings, 8th International Congress on Catalysis, Berlin, 1984", Vol. 4, p. 519 (1984), Dechema, Frankfurt-am-Main.

18) Hölderich, W., Eichhorn, H., Lehnert, R., Marosi, L., Mross, W., Reinke, R., Ruppel, W., Schlimper, H., "Proceedings, 6th International Conference on Zeolite, Reno, 1984" (D. Olson and A. Bisio, Eds.), p. 545 (1984), Butterworths, London.

19) Ione, K. G., Vostrikova, L. A., Petrova, A. V., Mastikhin, V. M., "Structure and Reactivity of Modified Zeolites" (P. A. Jacobs et al., Eds.), p. 151 (1984), Elsevier, Amsterdam.

20) Ball, W. J., Dwyer, J., Garforth, A. A., Smith, W. J., "Proceedings 7th International Conference on Zeolites, Tokyo", (Y. Murakami, A. Iijima, J. W. Ward, Eds.), p. 137 (1986), Kodansha, Tokyo.

21) Derouane, E. G., Nagy, J. B., Dejaifve, P., van Hooff, J. H. C., Spekman, B. P., Védrine, J. C., Naccache, C., J. Catal., 53, 40 (1978).

22) Anderson, J. R., Foger, K., Mole, R., Rajadhyaksha, R. A., Sanders, J. V., J. Catal., 58, 114 (1979).

23) Inui, T., Sekiyu Gakkaishi, 28, 279 (1985).

24) Inui, T., Nagata, H., Daito, N., Miyamoto, A., Chem. Express, 1, 455 (1986). 
鉄シリケート触媒上での低級オレフィンから高オクタン価ガンリンの高選択的合成

\author{
乾 智行, 岡住 文郎, 橪本 潤一, 山瀬 修, 松田 洋和 \\ 長田 秀夫, 大東昇, 宮本明
}

京都大学工学部石油化学教室, 606 京都市左京区吉田本町

石油危機以降, 石油代替然料への転換が進められ，重質油の 余剩傾向が強まったため, 重質油をより有効に利用する新しい 技術の開発が重要となってきている。本研究は, 重質油の熱分 解などにより生成するェチレン, プロピレン, ブテンなど低級 オレフィンを高オクタン価ガソリンへ高選択的に変換する触媒 の開発を目的として行われたものである。

触媒には, H-ZSM-5 の Al 成分を種々の金属成分に置き換 えたペンタシル型細孔構造を持つメタロシリケート類を用い た。これらは, アルミニウム塩の替りに他の金属塩を用いてシ リカ成分との混合ダルを形成させてから，著者らが開発した迅 速水熱合成法によって合成した。反応には，通常の常圧流通装 置 (Fig.1) を用いた。各種メタロシリケートの性能をプロピ レン転化で比較した結果，Al (すなわち ZSM-5)， Ga，V， $\mathrm{Cr}, \mathrm{Zr}$-シリケートは, 液状炭化水素のほかに, ガス状の $\mathrm{C}_{1}$ 〜 $\mathrm{C}_{4}$ パラフィンを約 $20 \sim 25 \%$ の選択率で生成した (Fig. 2)。 これに対し, $\mathrm{Fe}$-シリケートは, 定量的に液状炭化水素を生成
し (Figs. 2, 3)，また，極めて高い転化速度を実現できた。す なわち， $300^{\circ} \mathrm{C}, \mathrm{SV} 4,500 \mathrm{~h}^{-1}$ の条件で, プロピレン転化率 $95.6 \%$, 空時収量は実に $8.09 \mathrm{~kg} / l \cdot \mathrm{h}$ にも達した。 $\mathrm{Fe}$-シリヶ ートはブテン類 (Fig. 4)，エチレン (Fig.5) のガソリンへ の選択的転換にも高性能を発揮した。さらに, $\mathrm{Fe}$-シリヶート 触媒は反応温度, オレフィン濃度, 空間速度 (SV) の広い範囲 で高い反応速度とガソリン選択率を維持した（Figs. 6, 8, 9, 10)。対照的に, ZSM-5 の場合には, 反応温度の上昇に伴い, ガス状の $\mathrm{C}_{1} \sim \mathrm{C}_{4}$ パラフィンの生成が顕著になり，ガソリン選 択率は著しく低下した (Fig. 7)。なお，Fe-シリケート触媒に より合成されたガソリンのオクタン価は 95 といら高い値を示 したが，これは生成炭化水素が主にイソモノ内部オレフィンか ら成るためである (Tables 1, 2)。反応生成物中にコーク生成 の前駆物質となる苊香族炭化水素が少ないので, 活性低下は少 ないと予想されたが, 事実, 少なくとも100 時間反応を継続し ても贫化の兆候は見られなかった（Fig. 11)。

\title{
Keywords
}

Ferrosilicate, Gasoline synthesis, Metallosilicate, Olefin conversion 